\title{
A RESEARCH STUDY FOR COMPARING AND COMBATING THE WORST FORMS OF LITERACY AMONG THE CHILDREN WORKING AT BRICK KILN IN THE STATE OF TRIPURA
}

\author{
Nani Gopal Debnath \\ Post Graduate Teacher of Physics, Choudhury Bari Girls' H.S. School, Jirania. Tripura, \\ Agartala-799001, India; \\ Research Scholar, Department of Education, School of Education, Adamas University, \\ Kolkata, West Bengal, India \\ Dr. Prarthita Biswas \\ Associate Professor and Head, Department of Education \\ School of Education, Adamas University,Adamas Knowledge City Barasat, North 24 Prgs, \\ Kolkata, West Bengal, India
}

\begin{abstract}
Literacy condition of the children working in brick kiln in the state of Tripura as well as other state is practically very poor. During a long time this problem remains unsolved due to lack of strong policy and planning. For this worst condition of literacy, health and safety of those children, the responsible persons are the parents of the children, owner of brick field, state Govt. \& Central Govt. The condition is more pathetic in case of the migrant debt bondage labour families and their children. The parents are bound to engage their children as a labour due to their less wages and also due to the lack of awareness about education. They don't know that, only education can change the life of their kids. Their primary requirement is money due to which the parents pushes their children towards worse condition of their life. The Owner of the brick factories are not interested to improve the literacy condition of child labour due to their profit concern. Local Government is not giving emphasis on this matter as maximum of those labours are imported from other states. The middle man are the interstate labour brokers which also increases the intensity of exploitations. The basic problem lies in the fact that these labours are seasonal migrant labour.
\end{abstract}

So, it is most urgent to analyze the practical situation of literacy, health and safety of child labours in brick kiln and to provide recommendations for eliminating the worst forms of their life. 
A Research Study for Comparing and Combating the Worst forms of literacy among the children working at brick kiln in the state of Tripura

Key words: Brick kiln, child labour, debt bondage, exploitation, labour brokers, seasonal migration.

Cite this Article: Nani Gopal Debnath and Prarthita Biswas, A Research Study for Comparing and Combating the Worst forms of literacy among the children working at brick kiln in the state of Tripura, International Journal of Management (IJM), 11(12), 2020, pp. 3267-3273. http://iaeme.com/Home/issue/IJM?Volume=11\&Issue=12

\section{INTRODUCTION}

"Only education can change the life of a person "this universal truth should have in the mind and brain of each parents. We the supreme master of this globe should focus our educated mind for the universalization of elementary education in our country. Specially we should focus our mind for the privileged group of the society. In our country thousands of brick kilns are there in which lakhs of children working as a labour and not getting basic elementary education. Being self-less we should address this burning issue of our country. For this problem first of all we need to find out the basic problems regarding the issue and to analyze for eradicating the problems. One educated mother can educate the full family so it is urgent to give literacy to the mother of each children at first and simultaneously to the full family. The main tragedy of brick kiln is illiteracy of children working with their parents. So it the main target to address the issue in collaboration with mother state and migration state.

\section{OBJECTIVE OF THE STUDY}

- To describe the literacy condition of children working in brickfield.

- To identify the factors which affect the development of child labour including education, health and their safety.

- To analyze reasons why employers hire children $\&$ do not give education.

- To analyze reasons in which situation parents allow their children to work in brickfield.

- To analyze reasons why children accept to work in brickfield.

- To recommend remedial measures about eliminating the worst forms of education of children working in brickfield.

\section{LITERATURE REVIEW}

- worst forms of child labour.

- Worst forms of literacy of children in brick kiln industry.

- Cause of engaging children in brick factories.

- Impact of illiteracy on the children of brick kiln factories.

\section{RESEARCH GAP}

The search gap in this topic are as follows:-

- Permanent teaching method for kiln children of brick factories.

- Migration blended teaching policy on the education of children of brick factories.

- Health hazards of the children of brick kiln due to smoke and dust in the brick kiln factories.

- Allocation of working hours for children. 
- Allocation of study hours for children.

- Financial award to the parents of the children if they agree to provide education to their children.

\section{HYPOTHESIS}

- Parents will be agree to give education to their children

- State govt. will be initiated new policy for the child labour of brick kiln

- Owner of brick kiln will be more conscious about literacy among child labour working in their domain

- Inter state policy will be taken for the migrant child labour

- Exploitation of children will be reduced

\section{SAMPLES}

- Sample of child workers in the brick kiln

- Sample of parents of the children

- Sample of brick kiln managers

- Sample of brick kiln owners

\section{RESEARCH TOOLS}

- Questionnaire

- Observations

\section{DATA COLLECTION}

Data is collected directly by field visit. That means all the data are be primary data. Some data will be collected by open ended questionnaire and some by closed ended.

\section{PRESENT SCENARIO OF BRICK KILN IN TRIPURA}

The development of a state depends on its infrastructure and development of infrastructure depends on brick manufacturer. In our state above 500 brick kilns are there in which above 15000 workers are working, among which maximum are migrant labour. During October month they come to our state from different states of India with their full family including children. They starts their work in various brick manufacturing industries during winter season so that the rain can not herm their bricks before burning of the bricks. They work up to March i.e. up to before rainy season. In each brick industry approx. 40 to 45 Lakh bricks are produced per year and average selling price per brick is Rs.11 and labour cost per brick is approx.80 paisa and total manufacturing cost per brick is Rs. 6 .

\section{SCENARIO OF JIRANIA SUBDIVISION}

There are approx. 65 brick kiln are there within Jirania sub-division. In an average 300 workers are there among which maximum labours are migrant . 
A Research Study for Comparing and Combating the Worst forms of literacy among the children working at brick kiln in the state of Tripura

Table 1 Names of some important brick kilns and related information are tabulated below-

\begin{tabular}{|l|l|l|l|l|l|}
\hline Sl.no. & $\begin{array}{l}\text { Name of Brick } \\
\text { kiln at Jirania }\end{array}$ & $\begin{array}{l}\text { No. of } \\
\text { migrant } \\
\text { labour }\end{array}$ & $\begin{array}{l}\text { No. of } \\
\text { migrant } \\
\text { child labour }\end{array}$ & $\begin{array}{l}\text { No. of local } \\
\text { labour }\end{array}$ & $\begin{array}{l}\text { No. of local } \\
\text { child labour }\end{array}$ \\
\hline 1 & MKI & 300 & 150 & 40 & 06 \\
\hline 2 & KMI & 335 & 152 & 45 & 05 \\
\hline 3 & KBI & 289 & 129 & 52 & 04 \\
\hline 4 & SMI & 350 & 139 & 46 & 08 \\
\hline 5 & MKB & 289 & 150 & 25 & 04 \\
\hline 6 & MAA & 300 & 110 & 35 & 00 \\
\hline 7 & MMI & 315 & 120 & 36 & 06 \\
\hline 8 & NBC & 259 & 131 & 33 & 08 \\
\hline 9 & GLB & 269 & 151 & 45 & 00 \\
\hline 10 & JOYRAM & 301 & 153 & 52 & 13 \\
\hline 11 & OM & 350 & 158 & 41 & 12 \\
\hline 12 & SHIB & 311 & 143 & 25 & 00 \\
\hline 13 & LAXMI & 266 & 123 & 32 & 11 \\
\hline 14 & AMI & 299 & 124 & 25 & 12 \\
\hline 15 & JOY & 290 & 147 & 23 & 13 \\
\hline 16 & SBC & 290 & 159 & 25 & 00 \\
\hline & & & & & \\
\hline
\end{tabular}

\section{NEED OF BRICK KILN AT THIS TIME}

At this advance time it is very important to built solid durable building in which brick is very essential component. Bricks are significant basic material for all building \& constitute about $15 \%$ of the total building material cost . Bricks helps to adjust the temperature of building. We got financial benefit of brickwork in the long run. Brick protects our home from damage during storms. It is fire proof, durable over a long period of time. Low maintenance. Due to population explosion, urbanization and modernization the demand of bricks are increasing day by day.

\section{SOURCE OF MIGRANT LABOUR}

In the state Tripura migrant labours come from different states of India, these states are -

- Ranchi of Jharkhand

- Bihar

- Cooch behar of West Bengal

- Cachar of Assam

- Odisha

\section{MOTHER TONGUE OF MIGRANT LABOURS}

Due to different mother tongue of the children it is very difficult to provide them elementary education through their own mother tongue.

Table 2

\begin{tabular}{|l|l|}
\hline Worker from & Mother tongue \\
\hline Ranchi & Hindi \\
\hline Bihar & Bhujpuri \\
\hline Cooch behar & Bengali \\
\hline Cachar & Bengali \\
\hline
\end{tabular}




\section{LIVING CONDITION OF BRICK KILN LABOURS}

The living condition of each brick kiln labours are very pathetic ---

- Unhygienic living condition.

- Unscientific living method.

- Unscientific child birth process.

- Unscientific food cocking method.

- Consumption of impure water.

- Use of dirty cloths.

- Irregular bathing.

- No use of shampoo to clean hairs.

\section{LITERACY CONDITION OF CHILD LABOURS}

- Children are not getting primary education.

- Children can not write their name also .

- They are not familiar with their own letters and numbers.

- They can not read in their mother language.

- Parents do not have any interest regarding education of their kids .

- Owner of the brick kiln do not take the responsibility of primary education of the children working with their parents.

- State government also not taking any proper literacy program for them as they are not citizen of the state.

- They are not giving vote during election, so govt. has no headache for them.

- Mother state government also not taking any proper initiative for them as they stay there only for 5 months.

\section{HEALTH AND HYGIENIC CONDITION}

All the migrant labours lives in barbarous manner in temporary constructed house. The scenario their living place are as follows -

- They sleep on kaccha floor .

- They use kaccha toilet.

- Untreated impure drinking water collected from stream.

- They cock with wooden fuel which creates lots of smoke and harms their kids severely.

- They are very irregular regarding cutting of their nails and hairs as a result they suffers with different disease.

- They do not use proper detergent to wash cloths.

- They suffers with different types of health related problems such as -

- lower back pain.

$\circ$ hands pain

○ knee pain

○ wrists pain

○ shoulder pain . 
A Research Study for Comparing and Combating the Worst forms of literacy among the children working at brick kiln in the state of Tripura
○ neck pain.
○ respiratory problem
○ viral and bacterial disease
○ sculpt fungal disease.

\section{FINANCIAL CONDITION OF PARENTS}

The parents of the child labours suffers a lot with financial crisis due to their less wages. Per day average wages of the workers are Rs. 300 to Rs. 350 only which is very poor in comparison of present market price of common commodities.

Due to very less income the parents are not interested about the education of their kids. Also they are unable to fulfill proper medication demand of their family members specially for children and women during birth and after birth of a new baby. As a result the whole family suffers a lot with financial crisis generation after generation.

\section{CAUSE OF ENGAGING CHILDREN AS LABOURS}

There are several cause of engaging their kids as labour which are as follows -

- Due to less family income.

- Due to more number of children in the family.

- Due to unavailability of scope of education in side the brick kiln.

- Due to more work load of the parents

- Due to time bound target of production before rainy season.

○ Due to ignorance of the parents about the future of their kids.

\section{FACTORS EFFECTING DEVELOPMENT OF EDUCATION, AND SAFETY OF CHILDREN}

Several factors are responsible for the non-development of education, health and safety of children in brick kiln which are as follows -

- Illiteracy of parent workers.

- Ignorance of parents about literacy.

- Short time income target by their kids.

- Schooling of kids will reduce total income of the family.

- Quasi permanent residence in migrant state.

- Unscientific thinking of parents and employer.

- Careless literacy policy of their mother state.

- Careless thinking of their migrant state as they are not the part of vote bank.

- Careless and non-rigid universalization policy for elementary education

- Lack of proper implementation of education policy

- Non co-operation of NGO's for eradication of child labour

- Business thinking of employer

\section{PROBABLE MEASURES FOR IMPROVING THE CONDITION}

There may be some probable measures to improve the condition. We know that if there is a wish then there is a way. Ultimately we need positive approach towards the matter. By 
collaborative approach we can improve the worsen condition. The probable measures may be as follows -

- To impose strict policy on elementary education for the children of brick kiln.

- To introduce half-yearly schooling system in mother state and another half-yearly schooling in migration state for the migrant labour.

- Giving government incentive to the NGO's to develop new schooling infrastructure for them.

- Rapid counseling of parents to send their kids to take elementary education.

- Collaborative common policy framing in between mother state and migration state.

\section{CONCLUSION}

Universalization Elementary Education and Education for all this policy is very effective for our country but due to lack of proper implementation in the field still we are facing the child labour problem in our different states. We claim that we are developing country but in the literacy program some failures are there. By any means we need to address the problems regarding child labour. In the $21^{\text {st }}$ century it is one of the big curse in our society and obviously it is the matter of shame for the civilized educated society of the nation. We have to put our hands with head and heart to eradicate the illiteracy condition from every corner of our country .We need to love each children and need to treat them equally irrespective of cast, creed, colour, financial condition and society in which they belongs. All the stake holders like state government, central government, NGO's, society, parents and owners in the brick kiln should come forward with positivity to solve this long running problem regarding illiteracy of children working in the brick industries.

\section{REFERENCES}

[1] Dorman,Peter.(2008) ,Child labour Education and Health.Journal of Economics Literature37(3):1083-1119.doi:10.1257/jel.37.3.1083.

[2] Srivastava.K.(2011), Child labour issues and challenges, Indian Journal of Occupational Environment.

[3] Pratik (2020), Financial Literacy Among Brick Kiln Workers. Kings College London.

[4] Roy.S.K.(2016), Problem of Child labour in the brick fields of West Bengal

[5] Chiabu.J.(2017) Hazardous Child Labour in Nepal: The case of Brick Kilns, https://doi.org/10.1016/Elsevier Ltd.

[6] Daly.A.(2020), Bricks in the Wall: A review of the issues that effects children in the brick field, onlinelibrary.wiley.com.

[7] Sharma.B.(2019), Seasonal child labour in Nepal's Brick kilns,A study of its educational impact and parents'attitudes towards it,journal of education and work32(1):1-12

[8] Basu.K.(1999), Child Labour:Cause,Consequences, and Cure with remarks on International Labour standards. Journal of Economic Literature37(3):1083-1119.doi:10.1257/jel.37.3.1083.

[9] L.C.Schmitz,Traver. E.K.and Larson.d, (2004) Child Labour:A Global View.London:Greenwood Publishing Group.

[10] R,Ray(2002), The Determinants of Child Labour and Child Schooling in Ghana, Journal of African Economics 11(4):561-590.doi:10.1093/jae/11.4.561 